\title{
Conditions for collection of serum samples for the measurement of fibrin(ogen) degradation products by radioimmunoassay of fragment $E$
}

SYNOPSIS A number of conditions have been assessed for the collection of serum samples for the measurement of fibrin(ogen) degradation products using a radioimmunoassay for degradations fragment $\mathrm{E}$, which permits precise quantitation of differences. Blood should be collected using minimal venous occlusion into glass tubes containing $10 \mathrm{mg} / \mathrm{ml}$ of epsilon amino caproic acido and allowed to clot at 4 to $20^{\circ} \mathrm{C}$ for at least 4 hours before centrifugation. The serum may be stored at 4 or $-20^{\circ} \mathrm{C}$. Samples from patients receiving anticoagulant therapy should be treated with $10 \mathrm{IU}$ of thrombin per $\mathrm{ml}$.

Serum levels of fibrin(ogen) degradation products (FDP) have been used since 1961 (Ferreira and Murat, 1961) in the diagnosis and treatment of both disseminated and local intravascular coagulation. Fibrinogen and fibrin are degraded by the fibrinolytic enzyme system to produce a heterogeneous series of degradation products of decreasing molecular weight: only the earliest products in the chain retain the ability to clot (Marder et al, 1969). When FDP levels are measured in serum only the non-clottable molecules will be present, all others having been removed during coagulation. In preparing serum samples for the measurement of FDP it is essential to ensure that coagulation is complete; if it is not, the measured FDP levels will be falsely raised due to the persistence of clottable molecules. It is equally important to prevent activation of the fibrinolytic enzyme system during coagulation as this could also lead to an increase in levels in vitro. With these problems in mind, several workers have suggested conditions for the collection and preparation of serum samples for FDP determinations (table I).

FDP levels can be measured by a variety of immunological techniques including haemagglutination inhibition (Merskey et al, 1966), latex particle agglutination (Allington, 1971), immunoelectrophoresis (Niléhn and Nillson, 1964), and

Received for publication 28 July 1975 radioimmunoassay (Gordon et al, 1973; 1975a ; Plow and Edgington, 1973). The radioimmunoassay method has the advantages of high sensitivity and precision, and is thus well suited to the study of variables in sample collection and preparation. In the present study a number of these variables have been examined in detail.

\section{Material and Methods}

All blood samples were collected into plastic syringeso using minimal venous occlusion. The samples were ${ }^{3}$ aliquoted into glass tubes containing either (1) no additive, (2) $10 \mathrm{mg} / \mathrm{ml}$ amino caproic acids solution (EACA, Kabi Pharmaceuticals), (3) 250․ Kallikrein inactivator units $/ \mathrm{ml}$ aprotinin solution (Trasylol, Bayer Pharmaceuticals), (4) $10 \mathrm{mg} / \mathrm{mP}$ freeze-dried soybean trypsin inhibitor and 10 NIH units/ml thrombin (Wellcome Reagents), (5) $10 \mathrm{~W}$ NIH units/ml of freshly suspended thrombin (Parke Davis Ltd) and $10 \mathrm{mg} / \mathrm{ml}$ EACA, (6) as

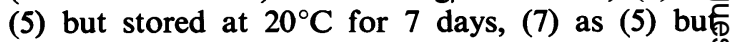
freeze-dried before use. Thrombin was also added? to the serum after separation. Incubation times of whole blood from 4 to 96 hours were studied ap $4^{\circ} \mathrm{C}$, and temperatures from $4^{\circ} \mathrm{C}$ to $37^{\circ} \mathrm{C}$ were studied for a fixed time of 24 hours. Serum was separated by centrifugation at $1500 \mathrm{~g}$ for 45 minutes and stored at either $4^{\circ} \mathrm{C}$ or $-20^{\circ} \mathrm{C}$ for up to 16 days. In one set of experiments the coagulation 


\begin{tabular}{|c|c|c|c|c|c|c|}
\hline Reference & $\begin{array}{l}\text { Method of } \\
\text { Venepuncture }\end{array}$ & $\begin{array}{l}\text { Added } \\
\text { Thrombin } \\
\text { (NIH units } / \mathrm{ml})\end{array}$ & $\begin{array}{l}\text { Added Enzyme } \\
\text { Inhibitor }\end{array}$ & $\begin{array}{l}\text { Time for } \\
\text { Coagulation } \\
\text { (h) }\end{array}$ & $\begin{array}{l}\text { Temperature for } \\
\text { Coagulation } \\
\left({ }^{\circ} \mathrm{C}\right)\end{array}$ & $\begin{array}{l}\text { Storage of } \\
\text { Separated Serum } \\
\left({ }^{\circ} \mathrm{C}\right)\end{array}$ \\
\hline Bonnar et al (1969) & Clean & 一 & $\begin{array}{l}\text { Tranexamic acid } \\
0.2 \mathrm{mg} / \mathrm{ml}\end{array}$ & ns & ns & ns \\
\hline Henderson et al (1970) & ns & 10 & - & 2 & 37 & -20 \\
\hline Stiehm et al (1970) & ns & 一 & - & $1-3$ & ns & ns \\
\hline Almér et al (1972) & ns & 10 & EACA $8 \mathrm{mg} / \mathrm{ml}$ & ns & ns & ns \\
\hline Briggs et al (1972) & ns & - & $\begin{array}{l}\text { Tranexamic acid } \\
0.4 \mathrm{mg} / \mathrm{ml}\end{array}$ & 4 & 20 & ns \\
\hline Merskey et al (1972) & $\begin{array}{l}\text { Minimum venous } \\
\text { occlusion }\end{array}$ & $1-5$ & EACA $0.05 \mathrm{M}$ & $0 \cdot 5-4$ & $0-21$ & 0 or -20 \\
\hline Bonnar (1973) & ns & 5 & $\begin{array}{l}\text { Aprotinin } \\
250 \mathrm{KIU} / \mathrm{ml}\end{array}$ & $2-8$ & 37 & -20 \\
\hline Hyde et al (1973) & Careful atraumatic & 2 & EACA $4 \mathrm{mg} / \mathrm{ml}$ & 2 & 37 & ns \\
\hline Naish et al (1973) & ns & 5 & EACA $0 \cdot 2 M$ & 3 & 37 & -20 \\
\hline Satterwhite et al (1973) & ns & 10 & EACA $4 \mathrm{mg} / \mathrm{ml}$ & 2 & 37 & ns \\
\hline $\begin{array}{l}\text { Wellcome Reagents Ltd. } \\
\text { (1973) }\end{array}$ & $\begin{array}{l}\text { No venous } \\
\text { occlusion }\end{array}$ & 10 & $\begin{array}{l}\text { Soybeant rypsin } \\
\text { inhibitor } \\
0.8 \mathrm{mg} / \mathrm{ml}\end{array}$ & 0.5 & $20-37$ & ns \\
\hline Gaffney et al (1974) & ns & $2 \cdot 5$ & $\begin{array}{l}\text { Aprotinin } \\
100 \mathrm{KIU} / \mathrm{ml}\end{array}$ & 1 & 37 & ns \\
\hline
\end{tabular}

Table I Methods of collection of serum samples for FDP assays

ns $=$ not stated

process was interrupted in the presence of EACA $(10 \mathrm{mg} / \mathrm{ml})$ by the addition of heparin $25 \mathrm{IU} / \mathrm{ml}$ (Weddel Pharmaceuticals) and immediate separation of the blood.

The $\mathrm{FgE}$ radioimmunoassay was performed as described previously (Gordon et al, 1975a). All the samples were assayed in duplicate at a $1: 10$ dilution, and EACA, aprotinin, soybean trypsin inhibitor, heparin, and thrombin were all tested for their ability to inhibit antigen-antibody binding. Three quality control sera were included in each assay performed, and comparative samples were always assayed in the same run. Results were compared by linear least squares regression analysis.

\section{Results}

When the coagulation process was interrupted by the addition of heparin there was a progressive decrease in $\mathrm{FgE}$ immunoreactive material in blood beginning within 10 minutes of exposure to glass by $20^{\circ} \mathrm{C}$; by 30 minutes only $0.4 \%$ of the initial activity was present at both $4^{\circ} \mathrm{C}$ and room temperature, and a further decline to $0.1 \%$ occurred by 2 hours (fig 1). Incubation of whole blood at $37^{\circ} \mathrm{C}$ in the absence of EACA resulted in an increase in FgE reactive material within 4 hours (fig 2 ). The results of the other studies are summarized in table II; incubation for longer than 4 hours at $4^{\circ} \mathrm{C}$ had no effect on $\mathrm{FgE}$ levels; at $37^{\circ} \mathrm{C}$ there was a significant rise at 24 hours. This rise was greater in the presence of aprotinin, and an even greater increase was seen with soybean trypsin inhibitor in spite of the presence of thrombin (fig 3). The addition of freshly suspended thrombin, either before (fig 4) or after centrifugation, caused an equal and significant reduction in FgE levels. The addition of

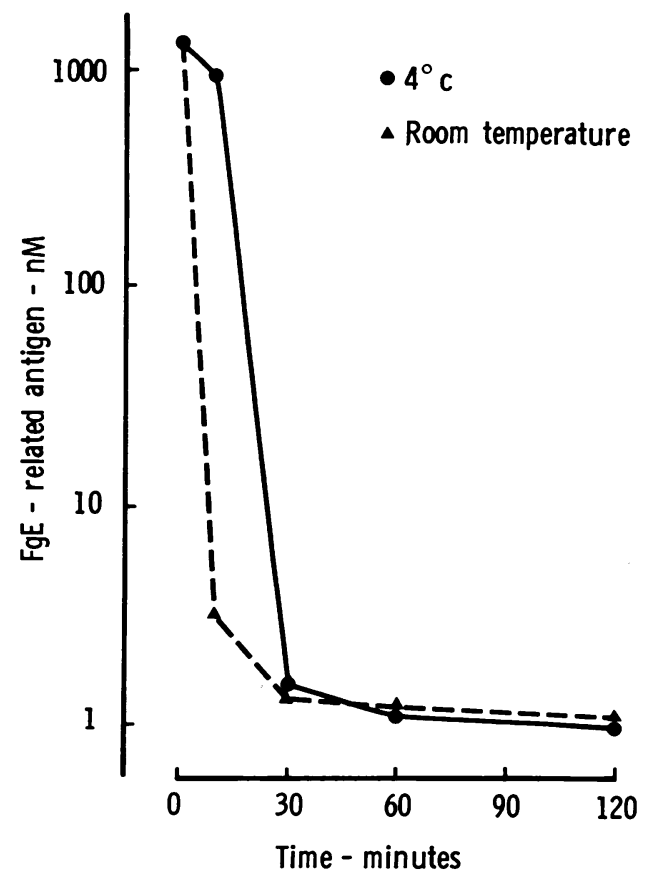

Fig 1 Progressive decrease in $F g E$ related antigen with time during coagulation at $4^{\circ} \mathrm{C}$ (—) and room temperature (- - - ). 


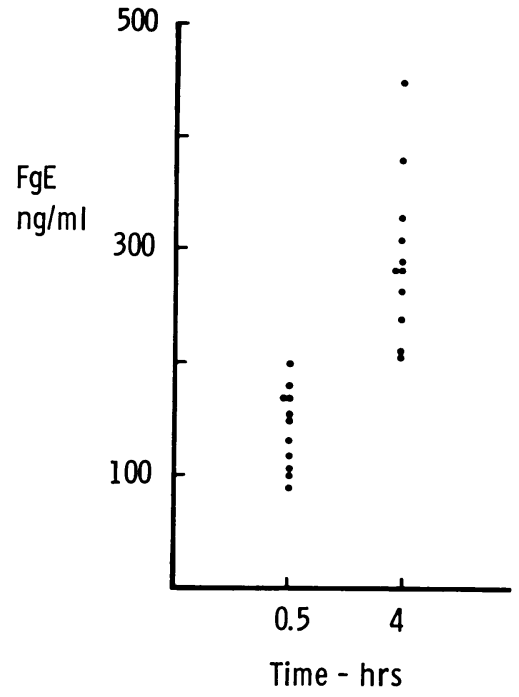

Fig 2 Effect of time on serum $\mathrm{FgE}$ levels of whole blood stored at $37^{\circ} \mathrm{C}$ in the absence of fibrinolytic enzyme inhibitors.

stored thrombin solution had no effect on results whereas freeze-dried material caused a significant increase in FgE levels. There was no difference in results between serum stored at $4^{\circ} \mathrm{C}$ or $-20^{\circ} \mathrm{C}$ to 10 days. No inhibition of antigen-antibody binding was observed with EACA, aprotinin, soybean trypsiñ inhibitor, heparin or thrombin at the concentrationsused for the collection of serum.

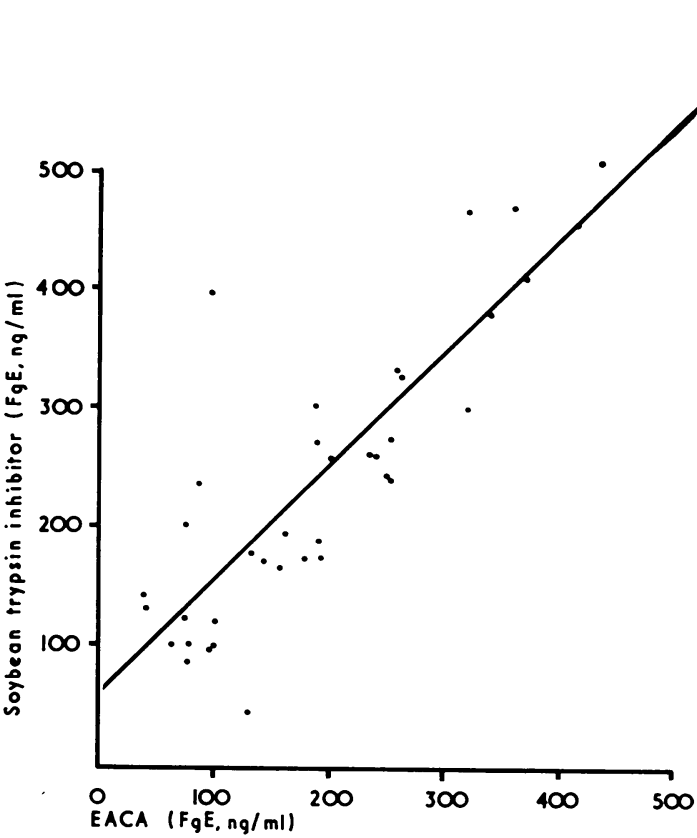

Fig 3 Serum FgE levels $(\mathrm{ng} / \mathrm{ml})$ in samples collected in the presence of EACA or soybean trypsin inhibitor: $r=0.84$, slope $0.96(\mathrm{P}>0.1)$, intercept $56(0.02>$ $\mathrm{P}>0.01$ ).

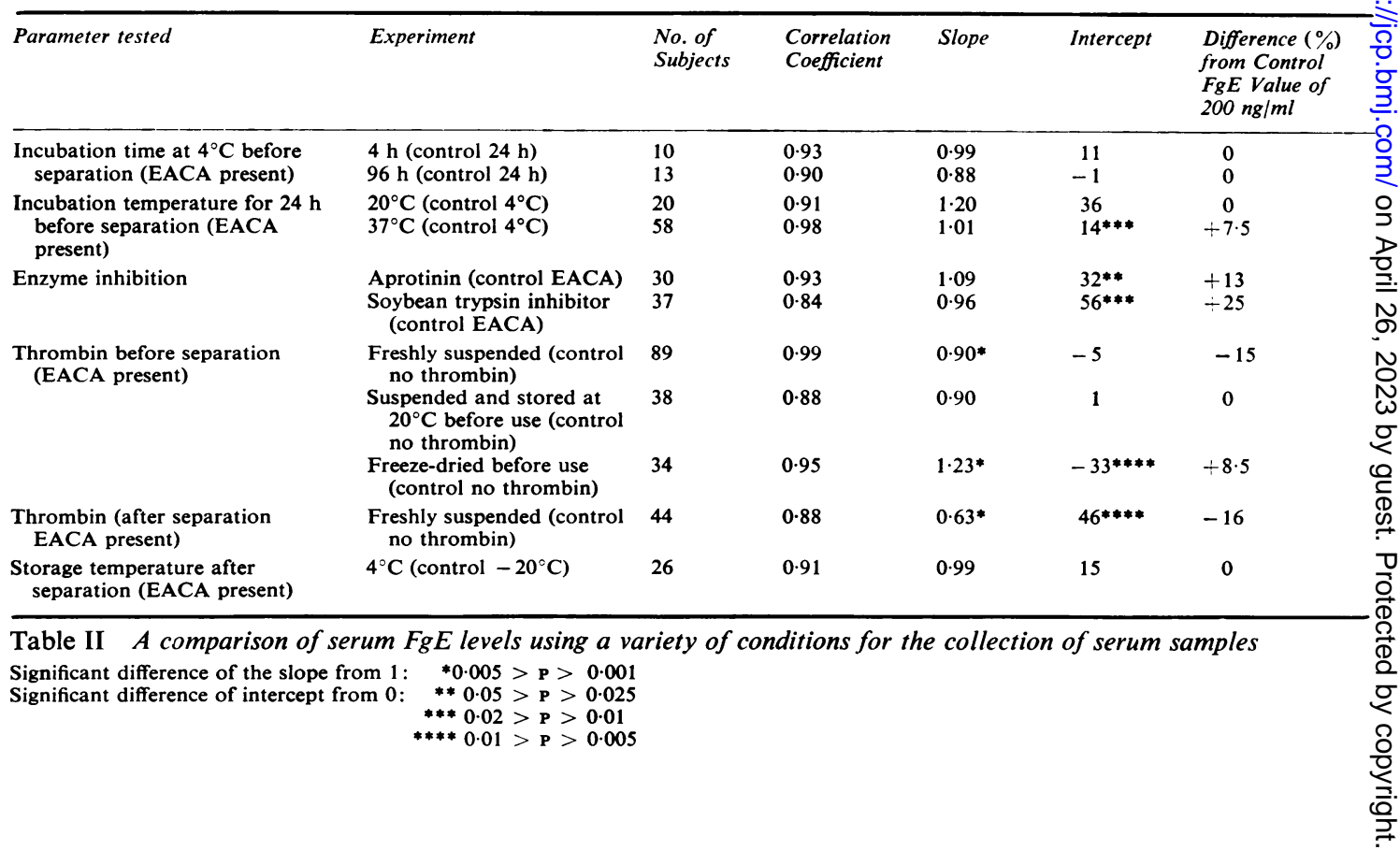




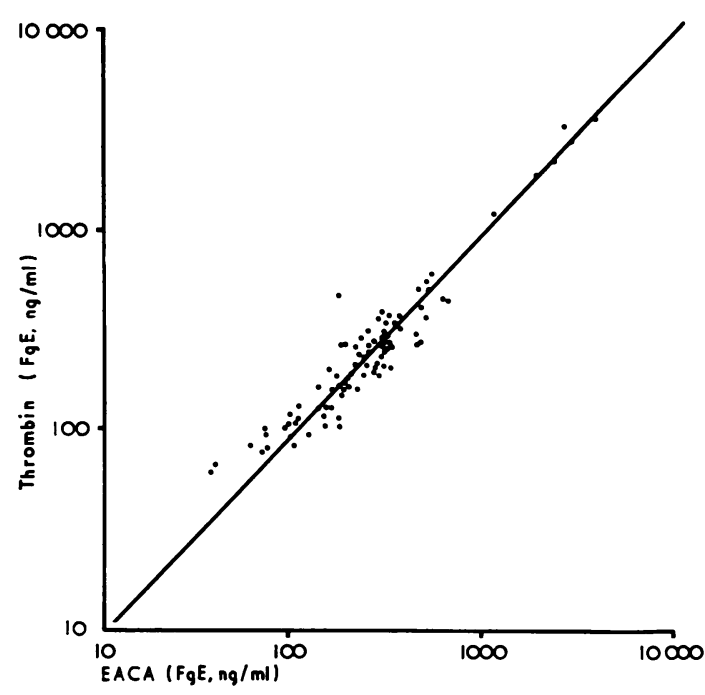

Fig 4 Serum FgE levels $(\mathrm{ng} / \mathrm{ml})$ in samples collected in the presence of $E A C A$ with or without freshly suspended thrombin: $r=0.99$, slope $0.90(0.005>\mathrm{P}>$ $0 \cdot 001)$, intercept $-5(\mathrm{P}>0 \cdot 1)$.

\section{Discussion}

There is only one previous study in which the optimal conditions for the collection of serum samples for FDP assay have been examined (Merskey et al, 1972). In the present investigation a variety of conditions have been evaluated in detail. To be of diagnostic value FDP levels in serum should reflect circulating degradation products and not an artefact due to either incomplete fibrinogen conversion or to activation of the fibrinolytic system. Activation of the coagulation system in vitro by contact with glass will activate the fibrinolytic enzyme plasmin. The extent of plasmin action will depend on the degree of activation and the time and temperature exposure. Although naturally occurring plasmin inhibitors are found in blood, plasmin is selectively concentrated within the fibrin mesh and may escape the effects of these inhibitors (McNicol and Douglas, 1972). In addition to plasmin, a number of other proteases including trypsin are able to degrade the fibrin molecule (Latallo et al, 1971). However, the results described here would indicate that in vitro degradation of fibrin is mainly due to plasmin. Thus EACA, which is a specific plasmin inhibitor (Brockway and Castellino, 1971), almost completely inhibited FDP formation in vitro, whereas less specific protease inhibitors (aprotinin and soybean trypsin inhibitor) produced only partial inhibition.
Activation of the fibrinolytic system occurs despite the presence of EACA when whole blood is incubated at $37^{\circ} \mathrm{C}$ for 24 hours. The presence of fibrin is essential since the effect is not seen with separated serum, as previously shown by Merskey and his coworkers (1972).

Optimal activation of the contact factors (XI, XII) of the coagulation system in vitro depends on a number of factors including time, temperature, calcium concentrations, and glass in contact with the blood (Nossel, 1972). In the absence of thrombin, coagulation is $96 \%$ complete within 10 minutes at $20^{\circ} \mathrm{C}$ and $99.9 \%$ complete within $60-90$ minutes at both $4^{\circ} \mathrm{C}$ and $-20^{\circ} \mathrm{C}$. The addition of freshly prepared thrombin produces significant reduction in the final concentration of FDP measured, and it seems likely that the concentration of endogenous thrombin produced in vitro is insufficient to coagulate all the clottable fibrinogen molecules. Observations on the nature of FDP in normal subjects (Divall, 1974) suggest that the material measured with immunological techniques consists mainly of soluble fibrin polymer of molecular weight greater than that of fibrinogen. These polymers contain partly degraded fibrinogen as judged by the ability of normal serum to cross react in the radioimmunoassay for the neoantigen of fragment $D$ which is specific for the degradation products of fibrin(ogen) (Gordon et al, 1975b). The presence of additional exogenous thrombin probably completes the coagulation of these partially degraded, high molecular weight fragments, whether added before or after separation of the serum. However, from the point of view of routine use, the disadvantage of thrombin addition is that the solution cannot be freeze-dried nor can it be stored at room temperature. The use of thrombin should probably be confined to those patients on anticoagulant therapy. In the present study, the findings of Merskey and his coworkers (1972) that thrombin will cause an elevation of FDP levels has not been confirmed. This discrepancy may perhaps be explained by the lack of sensitivity and precision of the tanned red cell haemagglutination inhibition assay used in the previous study.

Venous occlusion has been shown previously to cause a rise in the serum levels of $\mathrm{FgE}$ related to the rise in haematocrit and therefore due to haemoconcentration (Butler et al, 1975).

In conclusion, the optimum procedure for the collection of blood for FDP assay is as follows: samples should be taken using minimal venous occlusion into glass tubes containing $10 \mathrm{mg} / \mathrm{ml}$ of EACA and allowed to clot at $4{ }^{\circ} \mathrm{C}$ to $20^{\circ} \mathrm{C}$ for at least 4 hours before centrifugation. The serum may be stored at either $4^{\circ} \mathrm{C}$ or $-20^{\circ} \mathrm{C}$. Samples 
from patients receiving anticoagulant therapy should be treated with 10 units of thrombin per $\mathrm{ml}$ of blood.

YBG was supported by a Blair-Bell Memorial Fellowship from the Royal College of Obstetricians and Gynaecologists.

\section{References}

Allington, M. J. (1971). Detection of fibrin(ogen) degradation products by a latex clumping method. Scand. $J$. Haemat., Supplement 13, 115-119.

Almér, L. O., Hedner, U., and Nilsson, I. M. (1972). Serum fibrin/fibrinogen degradation products in acute myocardial infarction. (Letter.) Lancet, 1, 960.

Bonnar, J. (1973). Personal communication.

Bonnar, J., Davidson, J. F., Pidgeon, C. F., McNicol, G. P., and Douglas, A. S. (1969). Fibrin degradation products in normal and abnormal pregnancy and parturition. Brit. med. J., 3, 137-140.

Briggs, J. D., Prentice, C. R. M., Hutton, M. M., Kennedy, A. C., and McNicol, G. P. (1972). Serum and urine fibrinogen-fibrin-related antigen (F.R.-antigen) levels in renal disease. Brit. med. J., 4, 82-85.

Brockway, W. J. and Castellino, F. J. (1971). The mechanism of the inhibition of plasmin activity by $\mathrm{E}$-aminocaproic acid. J. biol. Chem., 246, 4641-4647.

Butler, M. J., Smith, M., Irving, M. H., Gordon, Y. B., Ratky, S. M., Rivers, J. W. P., and Hawkey, C. (1975). The influence of beta-adrenergic blockage upon baseline blood coagulation and fibrinolytic activity and upon the responses to venous occlusion. Thrombos. Diathes. haemorrh. (Stuttg.), 518, 169-180.

Divall, G. B. (1974). Studies on fibrinogen and fibrin degradation products as an aid to the identification of bloodstains in forensic science. Ph.D. Thesis, p. 115.

Ferreira, H. C. and Murat, L. G. (1961). Fibrina livre em circulacão. Teste immunológico para idenfificacão da fibrino livre. Rev. paul. Med., 59, 103-105.

Gaffney, P. J., Chesterman, C. N., and Allington, M. J. (1974). Plasma fibrinogen and its fragments during streptokinase treatment. Brit. J. Haemat., 26, 285-293.

Gordon, Y. B., McNeile, A. T., Martin, M. J., and Chard, T. (1973). Specific and sensitive determination of fibrinogendegradation products by radioimmunoassay. Lancet, 2 , $1168-1170$.

Gordon, Y. B., Martin, M. J., Landon, J., and Chard, T. (1975a). The development of radioimmunoassays for fibrinogen degradation products: fragments $D$ and $E$. Brit. J. Haemat., 29, 109-119.

Gordon, Y. B., Martin, M. J., McNeilly, A. S., Rees, L. H., and Chard, T. (1975b). Observations on Radioimmuno $\stackrel{\frac{0}{5}}{\overrightarrow{5}}$ assays for Neo-antigenic Sites in RIA and Related Topics. in Clinical Biochemistry. Heyden and Son (In press). Henderson, A. H., Pugsley, D. J., and Thomas, D. Pơ (1970). Fibrin degradation products in pre-eclamptio toxaemia and eclampsia. Brit. med. J., 3, 545-547.

Hyde, E., Joyce, D., Gurewich, V., Flute, P. T., and Barrera S. (1973). Intravascular coagulation during pregnancy and the puerperium. J. Obstet. Gynaec. Brit. Cwlth., $80 \AA$ 1059-1066.

Latallo, Z. S., Teisseyre, E., Wegrzynowicz, Z., an $\AA^{\circ}$ Kopéc, M. (1971). Degradation of fibrinogen by proteo $\overrightarrow{0}$ lytic enzymes. Scand. J. Haemat., Suppl., 13, pp. 15-19.

McNicol, G. P. and Douglas, A. S. (1972). In Humar Blood Coagulation, Haemostasis and Thrombosis, edited by R. Biggs, p. 393. Blackwell, Oxford.

Marder, V. J., Shulman, N. R., and Carroll, W. R. (1969)? High molecular weight derivatives of human fibrinogere produced by plasmin. 1. Physicochemical and immunological characterization. J. biol. Chem., 244, 2111-2119. के

Merskey, C., Johnson, A. J., and Lalezari, P. (1972). Increas in fibrinogen and fibrin-related antigen in human serumb due to in vitro lysis of fibrin by thrombin. J. clin. Invest.? 51, 903-911.

Merskey, C., Kleiner, G. J., and Johnson, A. J. (1966) D Quantitative estimation of split products of fibrinogen in human serum, relation to diagnosis and treatment. Blood, 28, 1-18.

Naish, P., Clark, A. D., Winston, R. M. L., and Peters D. K. (1973). Serum and urine fibrinogen derivatives in normal pregnancy and preeclampsia. Obstet. and Ginec. 42, 861-867.

Niléhn, J-E. and Nilsson, I. M. (1964). Demonstration of fibrinolytic split products in human serum by an immuno응 logical method in spontaneous and induced fibrinolytio states. Scand. J. Haemat., 1, 313-330.

Nossel, H. L. (1972). In Human Blood Coagulation, Haemo stasis and Thrombosis, edited by R. Biggs, p. 79. Blackwell음 Oxford.

Plow, E. and Edgington, T. S. (1973). Immunobiology of fibrinogen. Emergence of neoantigenic expressions during physiologic cleavage in vitro and in vivo. J. clin. Invest 52, 273-282.

Satterwhite, T. K., Hawiger, J., Burklow, S. L., and Koenig., M. G. (1973). Degradation products of fibrinogen and fibrin in bacteremia due to gram-negative rods. J. infect Dis., 127, 437-441.

Stiehm, E. R., Kennan, A. L., and Schelble, D. T. (1970) Split products of fibrin in maternal serum in the perinatalo period. Amer. J. Obstet. Gynec., 108, 941-945.

Wellcome Reagents Ltd. (1973). Detection of Fibrinogen Degradation Products and Fibrinogen. Wellcome Research Laboratories, Beckenham, Kent. 